\title{
THE ISRAELI LAW'S ATTITUDE TOWARDS MINORS' RIGHTS OF PARTICIPATION IN MAKING DECISIONS RELATING TO THEM
}

\begin{abstract}
Khawaly-Esawi Rita, The Israeli Law's Attitude Towards Minors' Rights of Participation in Making Decisions Relating to Them [Podejście prawa izraelskiego do prawa małoletnich do podejmowania decyzji ich dotyczących]. Studia Edukacyjne nr 41, 2016, Poznań 2016, pp. 425-445. Adam Mickiewicz University Press. ISSN 1233-6688. DOI: 10.14746/se.2016.41.25
\end{abstract}

The purpose of the paper is to examine the attitude of Israeli law towards minors' participation in making decisions relating to them. This right is expressed in the United Nations Convention on the Rights of the Child which has turned into an international document approved by nations all over the world. The minor's right to participate in decisions relating to him is enshrined in Section 12 of the United Nations Convention on the Rights of the Child. It is possible to see that the convention recognized the dignity of the person and the human rights of the minor. However, it is willing to grant rights to minors taking into consideration their age and their different stages of development. Sometimes parents focus mainly on their own interest and rights, and thus find it hard to faithfully determine their children's rights and protect their best interest. If a minor does not have the right to participate in legal proceedings relating to him, he might get hurt. The view which accepts the notion of independent representation of a minor stems from the concept that a minor has rights like adults, and those rights include one to independent representation. Such a right can be practiced when the minor himself, his guardian or lawyer, represents his interests independently from his parents.

Israeli law generally does not provide minors with independent rights such as the right to be a part of decision making. However, it does provide minors with rights in specific cases which might be seen as necessary, and there is still considerable space for the personal worldview of the judge. In addition, Israeli law is yet to adequately define the exact role of the legal guardian representing a minor and his methods of operation, and nowadays this duty depends on the personality of a legal guardian and his approach to this duty.

Key words: minors' rights, minor's best interests, independent representation, autonomy 


\section{Introduction}

"A minor is a human being; he is also a person who has small proportions. A person; despite being a minor; is entitled to all the rights that adults have". ${ }^{1}$ According to Israeli law; a minor is someone who is below 18 years old. ${ }^{2}$ Parents are the natural guardians of their underage children. The parents' guardianship includes the duty and the right to care for the minor's needs, including educating him, caring for his studies, training him for work, a profession and employment, protecting his assets, managing and developing them; And with it comes the authority to hold a minor determine his place of residence and the authority to represent him. The minor must, in filial piety, obey his parents in any matter regarding his guardianship. ${ }^{3}$

Most countries draft laws which protect minors and this is due to the assumption that minors do not possess the ability to care for themselves and their physical and mental needs, are not able to support themselves, and do not possess a mature judgment. Examples for such protection laws include laws which prohibit the publication of a minor's picture and name; laws prohibiting the conversion of a minor's religion; laws prohibiting the sale of cigarettes and alcohol to minors, mandatory attendance in schools, the need for a representative's approval for legal proceedings (such as signing contracts or opening bank accounts), limits on issuing driving licenses to minors; separate legal proceedings and penalties (such as teen courts), laws governing the employment of minors, and other laws protecting minors from abuse and exploitation. However, a part of these laws, which are supposed to protect minors, actually impose restrictions on their rights.

Sometimes parents focus mainly on their own interest and rights, and thus find it hard to faithfully determine their children's rights and protect their best interest. If a minor does not have the right to participate in legal proceedings relating to him, he might get hurt. The view which accepts the notion of independent representation of a minor stems from the concept that a minor has rights; like adults, and those rights include the right to independent representation. Such right can be practiced when the minor himself, a guardian of his or a lawyer, represents his interests independently, separately from his parents. In this context, it should be taken into account,

\footnotetext{
1 As said by judge Cheshin in Anonymous v attorney general, Appl. no. 6106/92, 27 September 1993, Court ruling 48(2), 1, p. 836, 833.

2 Sec 3, The Legal Capacity and Guardianship Law, 1962.

${ }^{3}$ Sec 14 and 15, The Legal Capacity and Guardianship Law, 1962.
} 
among other things, the rights which are available to each person as included in the legislative provisions of the Basic Law; Human Dignity and Liberty. A minor who is relatively mature, or possesses a high degree of maturity, can represent himself, however, due to the fact that generally. a minor will find it hard to represent himself against an adult, the right for independent representation could be exercised in the best way by hiring a lawyer, or a legal guardian who is not a lawyer, for the purpose of representing the minor. ${ }^{4}$ These could replace the natural guardians; the parents, and would represent the best interests of the minor. The purpose of the paper is to examine the attitude of Israeli law towards minors' participation in making decisions relating to them, when this right is usually expressed in the United Nations Convention on the Rights of the Child ${ }^{5}$ which has turned into an international document approved by nations all over the world.

The minor's right to participate in decisions relating to him is enshrined in Section 12 of the United Nations Convention on the Rights of the Child6, which states:

1. Participating countries will provide an underage child who is capable of forming his own opinion the right to express his opinion openly regarding all issues relating to him, while giving proper importance to his views; depending on the age and maturity of the underage person.

2. For the aforementioned reason, the opportunity to express an opinion will be given to an underage person in every judicial or administrative proceeding relating to him directly or indirectly, through a representative or any suitable entity, in an appropriate way following the rules of international law.

The Israeli law includes two basic bills providing guidance for determining a minor's fate: The principle of a minor's best interests and the principles of a minor's rights. The accepted definition of principle of a minor's interests relies on the assumption that the child needs to develop physically, mentally, morally, spiritually and socially in a healthy and normal way; the concept of the principle of the minor's interests dictates that a child is not an object - a property or something similar - belonging to his parents, but he is a subject with independent personality, rights and needs for himself. The principle of the minor or child's best interests provides guidance in the Israeli law regarding guardianship, custody, visitation rights, etc. Among other things, this principle stems from the provisions of the International Convention on the Rights of the Child ${ }^{7}$. Section 3 of this Convention states:

\footnotetext{
4 A.M. Haralambie, The Child's Attorney: A Guide to Representing Children in 107 Custody, Adoption and Protection Cases, 12-14 (1993).

5 The Convention on the Rights of the Child, 1989.

${ }^{6}$ See footnote number 6 .
} 
"With regards to all proceedings related to children; whether made by private or public social welfare institutions private or by courts of law, administrative authorities or legislative bodies, the best interests of the child shall be a primary consideration". ${ }^{7}$

In the second half of the 20th century, the concept of "Child rights" started to form. It differs from the "best interests of the child" in the fact that it is based on the independent will of the minor - at any time or any appropriate circumstances - and his ability to understand and make decisions related to his fate. Since it is important to recognize the privacy, independent and unique personality of all human beings, at all ages, it is important to recognize the rights of children. It should be noted that the rights of the minor are independent and separate from that of his parents. As stated, the principles of the rights of the child are reflected in different chapters of the Convention on the Rights of the Child.$^{8}$ Rulings of the Supreme Court of Israeli which discusses the status of child rights did not provide a noticeable breakthrough towards adopting the "Children Rights" doctrine and preferring it over the "Interests of the Child" doctrine. 9

The participation of the child is considered one of four principles which constitute the Convention ${ }^{10}$ and represents the most important innovation in the Convention. ${ }^{11}$ The joining of Israel to such convention constitutes recognition of the independent rights of minors, and not being subject to the rights of others only. However, due to the fact that Israel did not pass the Convention as a law, it does not have the legal weight of an official law, but only as an interpretive inspiration. ${ }^{12}$

\section{The Israeli legislative arrangement regarding the representation of minors}

The basic principles of Israeli law regarding the law of parents and children are largely made up of patchwork from the Ottoman legislation, from

\footnotetext{
${ }^{7}$ Sec 3, The Convention on the Rights of the Child, 1989.

${ }^{8}$ Kaplan Y., From the Interests of the Child to the Rights of the Child - Independent Representation of Minors, 2001, p. 1 (Hebrew).

${ }^{9}$ Ibidem.

10 The three other principles are the principle of equality, the principle of the interests of the child, and the principle of life, survival and development.

${ }^{11}$ Ministry of Justice, The subcommittee report on "Children and their Families", 2003 (Hebrew).

12 The Supreme Court ruling, The American European Missions v. social workers, Appl. no. (103/67), Court ruling 21(2), p. 325, 333.
} 
the mandatory legislation and legislation in Israel. These legal sources reflect different concepts and principles, which are often incompatible in with regards to the relationship between a child, his family and country. This complex legal situation has been complimented by the International Convention on the Rights of the Child since the State of Israel joined the convention which requires the Israeli legislation to adapt the Convention. ${ }^{13}$ In terms verdict, it shows that during the fifties there were already notable rulings given by the Supreme Court dealing with the question of the importance given to a minor's decisions concerning his custody. ${ }^{14}$ One can find a variety of opinions in these rulings as to the importance given to the wishes of the child. ${ }^{15}$ However, these judgments apply to these specific cases where children's opinions were heard, but there was no reference whatsoever to the participation in judicial proceedings. ${ }^{16}$ Since the mid-nineties, even before the committee submitted its reports ${ }^{17}$ (below: The Rotlevy committee), it is possible to find statements which express the recognition of the right of participation of minors. To quote judge Procaccia: "the right to be heard is available to both the parent and the child as part of the principles of natural justice" ${ }^{\prime 18}$

In the 1950's, many laws were passed in Israel to protect children's rights: the Compulsory Education Law ${ }^{19}$, the Law of Marriageable $\mathrm{Age}^{20}$, the

13 The Convention on the Rights of the Child, 1989, 31, p. 221. The countries have to adapt their legislation with the fourth chapter of this convention.

${ }^{14}$ Civil appeal, Wolf v. Wolf, Appl. no. 503/60, 1962, Court ruling 15, p. 766, 760.

15 The Supreme Court's view with regards to civil appeal, Tsabar v. Attorney General, Appl. No. 433/67 (1968), Court ruling 22(1), p. 166.

${ }^{16}$ See footnote number 15.

17 In June 1997, the Minister of Justice ordered the Committee of Children Law and Implementing Legislation (the Rotlevy Commission) who was asked to examine the need for legislation, including amendments to the laws of Israel, by adapting them to the obligations of the Convention and its principles. See Department of Justice, Committee of Children Law and Implementing Legislation: The Committee's report - The general part, 2003, p. 31-21.

18 Anonymous v. Anonymous, Authority of Citizen Appeal 3009/02, 20 June 2002, Court ruling p. 898,872 .

19 Compulsory Education Law (1949); which is often mislabeled as "Compulsory Study Law", states that every child in Israel has to belong to an educational institution (kindergarten or school). The Compulsory Education Law applies from age 3.

20 The Law of Marriageable Age (1950). In Israel, the minimum marriageable age is 17, for men and women, in 2013 the law was amended (Amendment number 6) and the marriageable age was increased to 18 , and it states that the family court can allow marriage for a person above the age of 16 , only when there are special circumstances relating to his good, justifying such a decision. 
Law of Public Education ${ }^{21}$, the Law of Teen Employmnt ${ }^{22}$, Amendments to the Law of Evidence (Protection of Children) ${ }^{23}$, the Law of Teen Care and Supervision. ${ }^{24}$ In 1962, the Law of Legal Capacity and Guardianship was passed; a law which is central in determining the legal relationship between parents and children.

Section 1 of the Legal Capacity and Guardianship ${ }^{25}$ law states: "Every person has rights and obligations from the moment he is born until his death". From this section we can conclude that every person has a legal personality and can gain rights and have obligations; however, in terms of legal capacity - i.e. in terms of content in the ability to win rights and have obligations - there is no equality between people. Humans do not equally enjoy all rights and do not possess the same obligations. ${ }^{26}$ The Legal Capacity and Guardianship law states the rules which reduce the scope of the legal capacity of a person. One is the age limit. Section 2 of the Law ${ }^{27}$ states: 'A person under the age of 18 years is a minor; a person above the age of 18 years is an adult". The legislature assumed that minors are not able to form their own independent will, a will that is mature and free of unwanted effects. The legislature's recognition of a minor's right to determine his own fate and future is usually dependent on the physical maturity, and there is little importance given to mental maturity. ${ }^{28}$

Generally the parents of a minor, his natural legal guardians ${ }^{29}$, are certified to represent his best interests. Section $15^{30}$ of the law states that the parents' legal guardianship includes, among other things, the "authority to represent him". Such authority could be applied according to the instructions of

${ }^{21}$ The Law of Public Education (1953). Dictates not only the right for education, but sets the values and the organization of education as a system which shapes future citizens.

22 The Law of Teen Employment (1953). The goal of the Law of Teen Employment is to guarantee the rights of working teens aged 15 to 18. Employing teens below the age of 14 is prohibited.

${ }^{23}$ Amendments to the Law of Evidence (Protection of Children) - 1955. This law regulates investigating children, be it as witnesses or as suspects.

24 The Law of Teen Care and Supervision (1960). This is a treatment law intended for the protection of the safety of minors.

${ }^{25}$ Sec 1, The Law of Legal Capacity and Guardianship, 1962.

${ }^{26}$ Engelrad Y., The Law of Legal Capacity and Guardianship, 1962, 1971, p. 319 (Hebrew).

27 Sec 2, The Law of Legal Capacity and Guardianship, 1962.

28 Shnet D., The Legal Capacity of a Minor and the Parental Authority to Represent Him, Society and Welfare, 1983(1), 7, p. 8-11 (Hebrew).

29 Sec 3, The Law of Women's Equal Rights, 1951; section 14 of the law of Legal Capacity and Guardianship, 1962.

30 Sec 15, The Law of Legal Capacity and Guardianship, 1962. 
the legislature included in section 17 of this law: ${ }^{31}$ "In their legal guardianship of a minor, parents have to act in the best interests of the minor, as any devoted parent would act in similar circumstances". In the past, following the paternalism-protectionism trends of the arrangements in the Law of Legal Capacity and Guardianship, judges determined the assumptions that the parents, the natural legal guardians, act in the benefit of their children and are supposed to set their acts in a way that benefits them, and when parents do so, it cannot be explicitly said or implied that the children were not represented or that they did not participate in decisions related to their custody. Under the right circumstances, the court of law might appoint a "legal guardian", as mentioned in section 68 of the law: 32 "The court is allowed, at all times, at the request of the attorney general or his representative, or at the request of a related party, and upon its own initiative, to take temporary or permanent measures which it deems fit, to save the interests of a minor either by appointing a temporary guardian or a legal guardian, or any other measures; and the court of law is allowed to do so if the minor does not have legal capacity, or if the underprivileged contacted the court directly.

Section 3 of the Law of Family Court ${ }^{33}$ states, among other things: "In any family matter related to the minor, the minor himself, or a close friend, is allowed to file a lawsuit related to any matters in which he feels that his rights were abused". Judge Gaifman wrote in his ruling ${ }^{34}$ that the authority, as stated by Section 3(D) of the Law of Family Court ${ }^{35}$, of for selfrepresentation of a minor, or being represented by a close friend, is different from the authority to appoint a legal guardian, as mentioned earlier, in Section 68 (A) of the Law of Legal Capacity and Guardianship. ${ }^{36}$ The assumption in Section 68 (A) is that the minor cannot decide what is good for him and thus a legal guardian should be appointed in order to present the best interests of the minor in the court of law. But judge Gaifman explained that when a minor is able to express an opinion, depending on his age and maturity, a lawyer should be appointed to him, and not a legal guardian. A lawyer represents the will of a minor, and does not draw conclusions himself, in a paternalistic way, separately from the minor, regarding the minor's best interests. Appointing a lawyer is giving respect for the minor's constitu-

\footnotetext{
${ }^{31}$ Sec 17, The Law of Legal Capacity and Guardianship, 1962.

${ }^{32} \mathrm{Sec} 68$ (D), The Law of Legal Capacity and Guardianship, 1962.

33 Sec 3 (D), The Law of Family Court, 1995.

${ }_{34}$ Anonymous v. Anonymous, Apple no. 23860/96, 20 May 1997, Family Ruling 97(2),

35 Sec 3 (D), The Law of Family Court, 1995.

${ }^{36}$ See footnote number 32.
} p. 3 . 
tional right to representation in a judicial proceeding. Article 32 of the law of Civil Procedure 37 allows a minor to sue or be sued in civil proceedings that are not done through his parents or legal guardians only. The section states: (A) A person of no legal capacity, "including a minor", due to the definition of section 1 of the law, is allowed to file a lawsuit through a legal guardian or a close friend, and he is allowed to be defended by a legal guardian. ${ }^{38}$

Different laws provide minors with a specific right to participate in decisions on certain matters related to him. For example, Section 13 A (B) of the Legal Capacity and Guardianship law ${ }^{39}$, which states, among other things, "If a minor reaches the age of 10, his religion will NOT be converted unless, in addition to his parents' approval or court approval, he provides a written consent in advance. Another examples can be found in Section 7 of the Child Adoption law ${ }^{40}$, which states: "If a minor is above the age of 9, or is below the age of 9 but has a basic understanding, he will not be adopted unless he shows up in court and states that he is interested in being adopted by the foster parent". It is possible to see that there is no professional sequence or a rational definition regarding the ages enabling minors to express their opinions, but the age difference is due to different legislative periods. ${ }^{41}$ Also, Section 316 of the Penal Code ${ }^{42}$ states that termination of a minor's pregnancy does not require the consent of her representative. She is fully entitled to terminate her pregnancy and seek the approval of the suitable committee. In the period after signing and confirming the International Convention on Children's Rights ${ }^{43}$, the Israeli legislation used an objective test of the minor's age and an individual test of his maturity. For example, Section 13 of the Convention on The Hague's Civil Aspects of International Child Abduction $^{44}$, sets some exceptions related to returning abducted children. One exception states: "The juridical or administrative authority can refuse to order the return of an abducted child if the child actually opposes the idea and he has reached the age and maturity level in which his reflections can be taken into account.

${ }^{37}$ Art 32, The Rules of Civil Procedures, 1984.

38 Sec 1, The Rules of Civil Procedures, 1984.

39 Sec 13 (A), The Rule of Legal Capacity and Guardianship, 1962.

40 Sec 7, The Child Adoption Law, 1981.

${ }^{41}$ Sec 13 (B), The Law of Legal Capacity and Guardianship, 1962; Sec 7, The Child Adoption Law, 1981.

42 Sec 316, The Penal Code, 1977.

${ }^{43}$ The Convention on the Rights of the Child, Charter 221, 311989.

${ }^{4} \mathrm{Sec} 13$, The Convention on The Hague's Civil Aspects of International Child Abduction, 1991. 
The legislature used these tests also in Article 295 I (E) in the Rules of Civil Procedure ${ }^{45}$ which states: "If a child was at the age and maturity level in which the court should take his reflections into account, the court will not make decisions in a claim without informing him, unless the court decides otherwise for special reasons which shall be documented" . A new concept related to the representation of a minor is reflected in Amendment number 11 of the Law of Teens (Care and Supervision), 1960, which amended Section 3 of the primary law. Section $3 \mathrm{~F}(\mathrm{~A})^{46}$ of the law regulates the status of a minor who objects to a psychiatric hospitalization: "According to section 4 (A) of the law of treatment of mental patients, with regards to a minor below the age of fifteen who does not agree to hospitalization by his designated representative, he will be the defendant". In this law, the legislature determined in subsection B of this section: "In such a case described in this section, the court of law will appoint a lawyer to represent the minor, unless the minor chooses to be defended by a lawyer on his behalf". ${ }^{47}$ Also, Section $3 \mathrm{G}(\mathrm{A})^{48}$ of the law determines that under the right circumstances, if a minor wishes to be admitted to a psychiatric hospital, his will should be respected. The section states: "Under the request of a minor, the court may order an examination or treatment on him, according to Article 25, section 3 B until Section 3 (E) of The Law of Teen Care and Supervision, 196049, even if not all the terms and conditions there are actually met, despite the objection of the person responsible for the minor, provided these two conditions are met: (1) the minor is above the age of fifteen. (2) The court is convinced that the minor understands the nature of the examination or treatment, and their implications, and he is interested in being examined or treated".

Another example can be found in Section 18 (A) of (The law of Trial, Punishment and Methods of Treatment of Teens) $)^{50}$ which states: The juvenile court may appoint a lawyer to the minor if it sees that it is for the benefit of the minor". In addition, if the juvenile court ordered the detention of a minor in a locked facility instead of imprisoning him, according to sections 25 (A) (1) or (2) of The law of Trial, Punishment and Methods of Treatment of Teens, the court of law may not provide a minor with an order unless an opportunity was given to the minor to present evidence and his arguments

\footnotetext{
${ }^{45}$ Art 295 I (E), The Rules of Civil Procedures, 1984.

${ }^{46}$ Sec 3 F (A), The Law of Teen Care and Supervision, 1960.

${ }^{47} \mathrm{Sec} 3 \mathrm{~F}$ (B), The Law of Teen Care and Supervision, 1960.

${ }^{48}$ Sec 3 G (A), The Law of Teen Care and Supervision, 1960.

${ }^{49}$ Art 25, sec 3 B until Sec 3 (E), The Law of Teen Care and Supervision, 1960.

${ }^{50}$ Sec 18 (A), The law of Trial, Punishment and Methods of Treatment of Teens, 1971.
} 
in this regard. ${ }^{11}$ In addition, Section $25 \mathrm{~A}(\mathrm{D})^{52}$ of the law states: "In a proceeding before juvenile court, according to this section, the court of law may appoint a lawyer to represent a minor who does not have a lawyer, and in this case, the provisions of the Public Defender apply. The legislature used these tests. Section 23 of the Child Adoption Law ${ }^{53}$ states: "The court of law may, at all times and even if it is not required, appoint a legal guardian for the adopted child for the requirements of the proceedings, according to this law". The Adoption Law in England also states that children constitute a side in the court proceeding and they have a right for legal representation. ${ }^{54}$ Section $28 \mathrm{~F}$ (B) of the Genetic Information Law ${ }^{55}$ states: "The court of law may not order the examination of a minor, as set in subsection (A), or a person without legal capacity, if this person and his representative did not consent to the examination, unless a lawyer or a legal guardian was appointed to represent him in legal proceedings before the court of law, as long as the minor or the person without legal capacity is not represented by a lawyer on his behalf". Section 8 of the Law of Teen Care and Supervision 56 states: "The court of law discussing the matters of a minor may, at all times, appoint a legal guardian for a minor, for matters arising from the proceeding before the court of law, if the court sees that this is required for the benefit of the child and to protect his interests.

From the above sections of the law we can note that the legislature distinguishes between appointing a lawyer and appointing a legal guardian to represent the minor, by the fact that in some sections the law states that in specific cases, only a lawyer should be appointed for the minor, and in other sections the legislation allows the appointment of a lawyer or a legal guardian. Therefore, it is possible to claim that in cases in which the legislature clearly states that a legal guardian should be appointed to a minor, the court of law should appoint an expert to represent the interest and benefit of the minor and not a lawyer. It is likely that today the approach taken by the court these days is to appoint a lawyer as a legal guardian representing the minor. Judge Gaifman states in his ruling57 that the division between circumstances justifying the appointment of a lawyer and the circumstances justifying the appointment of a legal guardian, stem from the problematic

\footnotetext{
${ }^{51}$ Sec 25 A (C), The law of Trial, Punishment and Methods of Treatment of Teens, 1971.

$52 \mathrm{Sec} 25 \mathrm{~A}$ (D), The law of Trial, Punishment and Methods of Treatment of Teens, 1971.

53 Sec 23, The Child Adoption Law, 1981.

${ }^{54}$ Sec 6, Adoption Act 197. (England).

55 Sec 28 F (B), The Genetic Information Law, 2001.

$56 \mathrm{Sec} 8$, The Law of Teen Care and Supervision, 1960.

57 See footnote number 34 .
} 
nature of representing young children. These children find it hard to formulate a clear statement regarding their desire and thus a lawyer is needed to face this difficulty: on one hand he is supposed to inform the court of his client's needs, and on the other hand he has a difficulty understanding these needs. Judge Gaifman bypasses such problematic issues by stating that a legal guardian should be appointed to a child who is not able to form his opinion, the duty of whom is to provide recommendations to the court on the basis of his benefit, rather than providing the court with the minor's desire. ${ }^{58}$ Representing the child according to his approach, given the aforementioned regarding the difference between the functions of a legal guardians and those of a lawyer, could sometimes be done by the two; One to represent the benefit of the minor and the other for his desire. Therefore, there will be an expression of the child's interests as a human being and also his best interests, as a minor, and in cases of a conflict (or alleged conflict), the court will find a balance in its ruling. In a later ruling of Judge Alon-Laufer, dated 10.06.1998, related to this request, the judge referred again to her previous ruling, as mentioned above, and concluded: "It was found that in principle it is possible to appoint a lawyer or legal guardian for a minor, and both in specific cases. A distinction was made between the two functions; between the desire of the minor and the best interests of the minor. According to Section 12 of the Convention, in matters affecting the child, his opinion should be given proper importance. In England, these sections provide guidance to the judge, guaranteeing the child's right to express his opinion in matters related to him, and especially the opportunity to be heard in legal proceedings, but they were not embedded in British law. The child still does not have an autonomous right to decide whether he wants to express his opinion in a legal proceeding. ${ }^{59}$

Despite the fact that in Israeli legislation, after joining the convention, it is possible to find a reference to the right of participation ${ }^{60}$ and the attempt

${ }_{58} \mathrm{~N}^{\prime} \mathrm{N}^{\prime}$ (not published), Apple no. 3420/96R. Judge Alon-Laufer's attitude towards, among other things, the existing ratio between appointing a legal guardian and appointing a lawyer. She even made a distinction between a minor who is able to express his opinion to a minor who is not. In a ruling dated 17.03.1998, she wrote: "The matter of representing a child could be and will be regulated by appointing a legal guardian or by appointing a lawyer to the minor on his behalf. The legal guardian replaces the minor's parents, who are the natural legal guardians.

59 Judge Potter M., The Child's Voice: "The rights of Children in Family Proceedings", 2008, p. 1.

${ }^{60}$ Morag T., "Court ruling after Israel joined the Convention of the Rights of the child - is it a new era?", 2006, p. 21, 22, 30-31 (Hebrew). 
of some judges to apply this right, especially the right to be heard ${ }^{61}$, it was obvious that the concept of participation cannot be applied fully and optimally, without embedding it in internal legislation. In 2004, the Minister of Justice received the recommendations of the Committee of Children Law and Implementing Legislation ${ }^{62}$, which formed six comprehensive reports after six years of work, and they included a suggestion for a comprehensive reform in Israeli legislation. In addition to the concrete recommendations of legislation which appear in the committee's reports, the importance of the committee's work is reflected in the fact that it constitutes the first attempt to build a wide perception related to the rights of children in the Israeli law. Some of the committee's recommendations are already embedded in Israeli law, and others are still considered experimental projects. ${ }^{63}$ The committee formulated a bill to promote children's rights ${ }^{64}$, which is intended to be a central law to be used as an umbrella for all government agencies dealing with children, and their attitudes towards children. The bill seeks to set a clear legislative base defining the responsibility and commitment of the state towards children, promote their rights and act in accordance with the principles of the convention. (The law's name is inspired from laws originating in England and Scotland, which propose a model for such regulation and are called Children Act). ${ }^{65}$ It is suggested that issues currently appearing in laws should be all regulated under one law which is the Law of Children. Among the laws suggested to be included in the Law of Children are: the

${ }^{61}$ Ibidem, p. 31 (Hebrew).

62 In June 1997, the Minister of Justice appointed the committee on the Children Law and Implementing Legislation (the Rotlevy committee below), which was asked to examine the need for legislation, including amendments to the Israeli laws, so they can be adapted to the state's obligations according to the Convention and its underlying provisions. See the Ministry of Justice, The Committee on the Children Law and Implementing Legislation: The Committee's Report 2003, p. 21-31.

${ }^{63}$ Morag T., The Effects of the Committee of the Examination of Child Rights and court rulings on the perception of Israeli rulings, 2008, p. 2 (Hebrew).

64 The Bill of Promoting Children's Rights, 2013. The bill was submitted to the Knesset in 13.3.13 but has yet to be approved as a law.

65 The Committee of Children Rights' Report - General Part - The Ministry of Justice, 2003, p. 21-31; http://www.justice.gov.il/Units/YeutzVehakika/NosimMishpatim/Havaad LeZhuyot/Pages/DochKliali.aspx. (Hebrew). In 1989 the Children Act was passed in England, which, among other things, was intended to meet the need of correction and compensation of children by providing better access to courts for children and more independent representations of minors 67 . The recognition and protection of the interests which are supported by rights renders our lives more human. Complete control and guidance should not be provided to the parents in relation to the lives of their children in order to protect them from foreign exploitation, because such a legal stance would deprive children of a very important right the right to act independently and separately from the parents. 
Law of Legal Capacity and Guardianship - 1962, The Law of Teen Care and Supervisions - 1960, The Law of Child Adoption - 1981, The Law of Regulation on Institutions for Minors - 1965, The Law of Protecting the Sheltered 1966 and the Relief Act (Provisions Related to Minors, the mentally ill and the absent) - 1955. Also, there is a bill intended to amend the Law of Teen Care and Supervision (The obligation of appointing a lawyer to represent a minor in a proceeding) which proposes the addition of Section $8 \mathrm{D}$ which states: "In proceedings according to Section 3 (4), the law of court will appoint a lawyer to represent the minor, unless the minor chose to be represented by a lawyer on his behalf" ${ }^{66}$ The proposed amendment is necessary as the parties involved in a proceeding, according to the Teen Law, are the parents and the social services, who may not represent the position of the minor. In specific cases, there is a conflict between the will of the parent and the will of the minor, and in other cases the parent is not in a position to determine the minor's best interests objectively, due to an emotional and sensitive state, which occurs in such proceedings. On the other hand, the social services' stance, despite the interests of the minor being clear to them, may not necessarily match the minor's will. As a result, the minor "will go unnoticed" by the sides involved in making decisions related to him, despite the fact that he should constitute a central figure in the consideration of the ruling. He faces "the adult world" alone, without a representative to protect his best interests.

\section{The duty of the representative}

The Israeli law is yet to adequately define the exact role of the legal guardian representing a minor, and his methods of operation, and nowadays such duty depends on the personality of the specific legal guardian and his views of his duty. It is possible to conclude from the law that appointing a lawyer as a legal guardian is not mandatory, because in order to protect the best interests of the child, a person with knowledge in dealing with children and teens is required, and not necessarily someone with legal expertise. For example, in England an external social worker from the welfare office

66 The Law of Teen Care and Supervision (Amendment - Appointing a Lawyer to Represent a Minor), 2011. Submitted to Knesset on 30.3.11 but has yet to be approved as a law. 
takes the role of the minor's legal guardian (guardian ad litem), and a lawyer specialized in Public Law and Rights is appointed to represent him. ${ }^{67}$

The Rotlevy's Bill for Separate Representation of Children in Civil ${ }^{68}$ Proceedings defines the obligation of appointing a lawyer as a representative for the minor according to the need for such appointment, and sets the age of 12 as the middle grounds between appointing a legal guardian, Representing the best interests of the minor, and between a lawyer representing the will of the minor. The bill also suggests the establishment of a unit which will engage in representing children; the unit will include lawyers and therapeutic consultants. Recognizing the uniqueness of the lawyer's duty in representing children, special obligations are imposed on lawyers representing children, including: the fiduciary duty towards the minor, the obligation of representing the minor with determination and dedication to protect his interests; the obligation of consulting with the minor and sharing with him all information about the proceedings; the obligation of giving information about the proceedings to the minor so he can formulate an educated desire; the obligation of meeting the minor and maintaining a constant contact with him; the obligation of explaining the role of the lawyer in the proceeding. With regard to babies or very young children who are not able to express their opinion, or are not in a position to provide a competent view due to their age, Judge Rotlevy said that due to their young age and inability to express their opinion, the duty of the legal guardian is to protect their best interests, in addition to all his rights, needs and interests and also providing him the option to be heard in the proceeding. The difficulty facing whoever represents very young children is the question of what his guidelines and scope of action are. The professional literature deals with the attempt of creating tools to fit the legal guardian so that his position will not be solely based on his own value system, namely, how he perceives the child's best interests, but in a more arranged way. Due to this, the committee even suggested to adopt a format for joint action between the legal guardian and the therapeutic advisor. ${ }^{69}$ In practice, in most countries children do not testify in court because the action is deemed as harmful.In addition, separate representation is provided in few cases only ${ }^{70}$, and only when there is a clear con-

67 "This system of dual representation is highly regarded for ensuring good quality child 30 representation" - taken from: Judith Masson, Representation of Children in England, Protecting Children in Child Protection Proceeding s, 34 Fam. L.Q. 467, 468 (2000).

68 The Law of Teen and Child Representation Bill, 2013, p. 93-114.

${ }^{69}$ See footnote number 68.

${ }^{70}$ To check the status in the country, please see The Ministry of Justice's report by the subcommittee on "Separate Representation of Children in Civil Proceedings", 2003 (Hebrew). For England, please see: Baroness Hale The voice of the child, \{2007\} INT'L. FAM. L.J. 171. 
flict between the interests of the child and those of his parents. ${ }^{71}$ Additionally, even when a legal guardian is appointed, the question of whether the court should hear the child's view directly or to order additional expert $f$ to listen to his representative, still arises. ${ }^{72}$

The American legal literature focuses on two approaches of the role of a legal representative: The best interests of the minor; And the will of the minor. According to the first approach, the legal representative has to decide what the best interests of the child are regardless of her wishes (in case the child expresses her opinion). According to the second approach, the representative has to express the wishes of the child, unless she is too young or has another difficulty making it hard for her to express her opinion. The American legislature generally chooses the approach of the child's best interests, while the American Bar Association (ABA) ${ }^{73}$ tends towards the approach of the child's wishes. ${ }^{74}$ In general, the ABA defined two separate duties for representation in cases of care and supervision: ${ }^{75}$ a representing lawyer (child attorney) and a legal guardian (guardian ad litem). The legal guardian constitutes an officer of the court, responsible for protecting the best interests of the child, but the duty of confidentiality is not imposed on him. Such representation will be given to very young children only. Child attorney: A lawyer who provides legal services to the minor and thus fiduciary duties are imposed on him, also confidentiality and providing effective representation for the child, guaranteeing that his consideration will be heard. The lawyer has to represent the preferences of the client and to act in court in accordance to his instructions. ${ }^{76}$

With regards to the difficulty faced by the representative, scholar Jean Koh Peter says:

We often become victims of our own counter-transference: our own conclusions about what an adult lawyer for a child should do or what a client's best interests are, based on our own values and experience. Indeed, with no clear guidance about our professional duties and the task of working with a child during some of the most

\footnotetext{
${ }^{71}$ Kaplan Y., "From the Best Interests of the Child to the Rights of the Child - Independent Representation of Minors, 2001, p. 623 (Hebrew).

72 Report by the subcommittee on "Separate Representation of Children in Civil Proceedings", 2003, p. 93-115.

73 ABA - The American Bar Association.

${ }^{74}$ Hunt Federle K., Children's Rights and the Need for Protection, 34 Fam. L.Q (2000) 425, 42.

75 Sobie M., The Child Client: Representing Children in Child Protective Proceedings, 22 Touro L. rev. 745 (2006).

76 See footnonte 75 .
} 
emotionally painfulcircumstances that can face a child, a parent, and a family, our own values and experience may emerge as our strongest guides. ${ }^{77}$

Over time, different schools of thoughts have developed in relation to the method of providing children with rights, the degree of rights ${ }^{78}$ and the level of protection given to children from wrongful rulings when such rights are used. These schools of thoughts are sometimes related to different views regarding the appropriate limit between maturity and being a minor.

Extreme schools of thoughts such as Children Liberationists and other extreme schools of thoughts, including the Family Welfarists, constitute an antithesis to the conservative thesis of the child liberation movement. As mentioned, these two approaches are extreme and are generally not accepted.

According to the school of thoughts of the children Liberationists, children should be treated as individuals with full citizenship rights. Among other things, they should be provided with the law of information, voting, incorporation, privacy and confidentiality, to grow free of poverty and discrimination, to leave the house and to get a job, to enter into contracts, to get married and to get medical treatment without informing their parents or getting their consent. ${ }^{79}$ The Family Welfarists schools of thoughts see the family as a central entity in society which plays an important role in raising children and supervising them. This school of thought takes the paternalisticproactive approach towards children. According to them, children should not be given independent rights and the parent's control and guidance is important. Children should be protected by preventing them from making basic decisions related to their lives, such as the decision to leave the house, choosing a study subject, and adopting a specific lifestyle. According to the supporters of this approach, parents or legal guardians should make important decisions related to the lives of the children. ${ }^{80}$ There is also a moderate approach which advocates providing children with rights while taking into account the counter arguments, which state that children do not always have legal capacity, enabling them to make reasonable and logical decisions, and sometimes they lack the wisdom coming from experience and they might

77 Peters J.K., Representing children in child protective proceedings: Ethical and Practical Dimensions (1997) page 44. Anonymous v. Anonymous the biological parents, Judge Rotlevy's ruling (Tel Aviv Court),apple no. 4/04, 20 December 2004.

78 Wald M.S., “Children's Right: A Framework for Analysis“ 12 U.C.L. Rev 255, 260-261 (1979).

79 Richard Parson, Birthrights, 1974.

${ }^{80}$ Alroi', “Children Rights, Different Views”, The Advocate, 1986, p. 272-275 (Hebrew). 
make a mistake due to this shortcoming. ${ }^{81}$ According to the moderate approach, one should be very careful when providing rights to children, simply because providing such rights might harm the harmony and autonomy of the family, and one should not abandon the children by providing them with rights that they do not know how to use wisely. ${ }^{82}$

\section{Summary}

"When determining the best interest of a child, one should take into account his rights, needs and interests" .83 Referring to children's rights is very important and essential, the child has independent rights, he is entitled to exercise his rights and not subject to others' rights only. The best interests of the child are protected by right and not due to compassion and paternalism by the court of law or other adults. ${ }^{84}$ Representing minors stems from a view that a child has rights 85 , similar to an adult. And thus he should be acknowledged as having the right of independent representation, a right which can be exercised fully when the minor himself, his legal guardian or lawyer represent his interests independently and separately from his parents ${ }^{86}$. While it recognizes human dignity and rights of minors, it allows providing minors with rights according to their age and development level.

The courts in Israel appoint more representatives for children and teens in proceedings related to them. However, so far only a few legal arrangements were made by law relating to the children's right of independent representation. The legislature does not provide children with independent rights such as the right to be a part of decision making. It states that others may make decisions related to children, in their best interests..$^{87}$ It provides minors with rights only in specific cases which the legislature thinks that

${ }^{81}$ Goldstein J., "Medical Care for the Child at Risk: On State Supervention of Parental Autonomy" 86 Yale L. J., 645 (1977); Goldstein J., Before The Best Interest of the Child 7 (1979).

82 Hafen B.C., "Children's Liberation and the New Egalitarianism: Some Reservations. About Abandoning Youth to Their 'Rights'" B. Y. U. L. Rev. 605-658 (1976).

83 The Ministry of Justice, Jerusalem, 2004, the General Part, p. 127-166 (Hebrow).

84 See: ANDREW BAINHAM, CLILDREN: THE MODERN LAW 102-103 (3rd ed., 2004) which explains the theory of interest by MacCormick.

${ }^{85}$ Katherine Hunt Federle, "Constructing Rights for Children: An Introduction", 27 Fam. 96 L. Q. 301-302 (1993-1994).

86 The Convention on the Rights of the Child, 1989.

87 See: Goldstein J., Medical Care for the Child at Risk: On State Supervention, Parental Autonomy; Also see: Sholmit Almog: "The Best Interests of Children in Comparison to 1977", “The Rights of Children", The Echo of Education, Issue 71, p. 11-12, 1996 (Hebrow). 
minors need it. The current legislation is irregular and does not set the grounds for appointing an independent representative for a minor, the methods of providing the representation and does not guarantee the quality of the provided representation. This differs from many countries around the world, including the US and England, where the right of independent representation for children was recognized and extensive systems were formed in order to regulate the right of independent representation for children.88 Recognizing the right of independent representation for children indicates the view which considers the child as a separate entity from his parents, with needs, rights and interests which sometimes might stand in contrast to those of his parents or other family members, and thus he is entitled to have these rights, needs and interests presented to the court. Legal representation ensures all the rights of children in the legal proceeding, and especially in legal proceedings dealing with the option of depriving children of their liberty, such as proceedings discussing the placement of a child within a locked hostel or a psychiatric institution.

As mentioned, there is no law in Israel which obligates the court to hear the child himself or his representative in relation to his will, or to take into account the child's will when there is a foreign guardianship, such as in relation to determining custody agreements, and no indication was given with regards to the importance that should be given to components and entities, and there is still considerable space for the personal world view of the judge. ${ }^{89}$

The legislation allows the appointment of a lawyer in specific cases, and in other cases it allows the appointment of a lawyer or a legal guardian, all at the discretion of the court. The Israeli law is yet to define the exact role of the legal guardian representing a minor, and his methods of operation, and nowadays such duty depends on the personality of the specific legal guardian and his views of his duty.

88 The subcommittee on "Separate Representation of Children in Civil Proceedings", The Ministry of Justice, 2003;

http://www.justice.gov.il/Units/YeutzVehakika/NosimMishpatim/HavaadLeZhuyot/ Pages/YezugNifrad.aspx.

89 A paragraph quoted by judge Rotlevy which admits to the drawback of this saying, Prof. Biron. "Regardless of such guidance, it has to be accepted that the world lacks and always will lack an accurate scientific measure or a philosopher's stone, which can be utilized to determine what, is truly in the child's best interests. Perhaps we ought to be honest and realize that although the best interest is the desired standard, in reality we are applying what we perceive as the best interests of the child or at least the less harmful". 
From what has been said above, there is a compelling need for a central law for the protection of the rights of children, according to the recommendations made by the Rotlevy Committee ${ }^{90}$, which will serve as an umbrella legislation to cover the obligations of the different government agencies dealing with children, and their attitudes towards children. Anchoring the committee's recommendations in legislation will promote not only the complete implementation of the rest of the recommendations, but will also guarantee the protection and realization of children's rights on equal basis with adults, independent of the attitudes of different judges. However, with regards to infants or very young children who are not able to express their opinion, either no weight will be given to their sayings due to their age, or a lawyer will be appointed in order to represent the minor and guarantee his rights in the legal proceeding related to him, in addition to the legal guardian whose role is promoting the interests of the minor and representing his benefits. In addition, it would be very important to set definitions, principles and guidelines regarding the methods of representing minors and the extent of such representation.

\section{BIBLIOGRAPHY}

The American Bar Association.

Adoption Act 1976. (England).

Almog S., "The Best Interests of Children in Comparison to 1977", "The Rights of Children", The Echo Of Education, 1996, 71 (Hebrow).

Alroi", "Children Rights, Different Views", The Advocate, 1986 (Hebrew).

Amendments to the Law of Evidence (Protection of Children) - 1955. This law regulates investigating children, be it as witnesses or as suspects.

Ann M. Haralambie, The Child's Attorney: A Guide to Representing Children in 107 Custody,

Adoption and Protection Cases, 1993.

Anonymous v. Anonymous the biological parents, Judge Rotlevy's ruling (Tel Aviv Court), apple no. 4/04, 20 December 2004.

Anonymous v. Anonymous, Apple no. 23860/96, 20 May 1997.

Anonymous v. Anonymous, Authority of Citizen Appeal 3009/02, 20 June 2002.

Anonymous v Attorney general, Appl. no. 6106/92, 27 September 1993.

BAINHAM A., CHILDREN: THE MODERN LAW 102-103 (3rd ed., 2004) which explains the theory of interest by MacCormick.

Baroness Hale The voice of the child, \{2007\} INT'L. FAM. L.J., 171.

B.C. Hafen, "Children's Liberation and the New Egalitarianism: Some Reservations About Abandoning Youth to Their 'Rights'" (1976).

90 The Law of Teen and Child Representation, 2013. 
Children Act, 1989 (England).

Civil appeal, Tsabar v. Attorney General, Appl. no. 433/67 (1968).

Civil appeal, Wolf vs. Wolf, , Appl. no. 503/60, 1962.

Compulsory Education Law (1949).

Engelrad Y., The Law of Legal Capacity and Guardianship 1962.

Goldstein J., Before the Best Interest of the Child 7 (1979).

Goldstein J., „Medical Care for the Child at Risk: On State Supervention of Parental Autonomy", 86 Yale L.J., 645 (1977).

Hunt- Federle K., "Constructing Rights for Children: An Introduction”, 27 Fam. 96 L.Q. 301-302 (1993-1994).

Hunt Federle K., Children's Rights and the Need for Protection, 34 Fam. L.Q (2000) 425, 42.

Judge Potter M., The Child's Voice: "The rights of Children in Family Proceedings", 2008.

Kaplan Y., "From the Best Interests of the Child to the Rights of the Child - Independent Representation of Minors, 2001 (Hebrew).

Masson J., Representation of Children in England. Protecting Children in Child Protection Proceeding s, 34 Fam. L.Q. 467, 468 (2000).

Ministry of Justice, The subcommittee report on "Children and their Families", 2003.

Morag T., "Court ruling after Israel joined the Convention of the Rights of the child - is it a new era?", 2006 (Hebrew).

Morag T., The Effects of the Committee of the Examination of Child Rights and court rulings on the perception of Israeli rulings, 2008 (Hebrew).

$\mathrm{N}^{\prime} \mathrm{N}^{\prime}$ (not published), Apple no. 3420/96.

Peters J.K., Representing children in child protective proceedings: Ethical and Practical Dimensions (1997).

Richard Parson, Birthrights, 1974.

The Bill of Promoting Children's Rights, 2014; http://www.justice.gov.il/ Units/YeutzVehakika/NosimMishpatim/HavaadLeZhuyot/Pages/DochKliali.aspx. (Hebrow).

The Child Adoption Law, 1981.

The Convention on The Hague's Civil Aspects of International Child Abduction, 1991.

The Convention on the Rights of the Child, (1989).

The Genetic Information Law, 2001.

The Law of Teen and Child Representation bill, 2013.

The Law of Teen Care and Supervision, 1960.

The Law of Teen Employment (1953).

The law of Trial, Punishment and Methods of Treatment of Teens, 1971.

The law of Family Court, 1995.

The Law of Women's Equal Rights, 1951; section 14 of the law of Legal Capacity and Guardianship, 1962.

The Legal Capacity and Guardianship Law, 1962.

The Law of Marriageable Age (1950).

The Law of Public Education (1953).

The Penal Code, 1977.

The Rules of Civil Procedures, 1984.

Shnet D, "The Legal Capacity of a Minor and the Parental Authority to Represent Him", Society and Welfare, 1983 (Hebrew). 
Sobie M., The Child Client: Representing Children in Child Protective Proceedings, 22 Touro L. rev. 745 (2006).

The Ministry of Justice, Jerusalem, 2004.

The Ministry of Justice, The Committee on the Children Law and Implementing Legislation: The Committee's Report 2003.

The subcommittee on "Separate Representation of Children in Civil Proceedings", The Ministry of Justice, 2003; http://www.justice.gov.il/Units/YeutzVehakika/Nosim Mishpatim/HavaadLeZhuyot/Pages/YezugNifrad.aspx.

The Supreme Court ruling, The American European Missions v. social workers, Appl. no. (103/67).

The Supreme Court's view with regards to civil appeal, Tsabar v. Attorney General, Appl. No. 433/67 (1968).

Wald M., “Children's Right: A Framework for Analysis “ 12 U.C.L. Rev. 255, 260261(1979). 
